\title{
Correction: Disease and patient characteristics in NP-C patients: findings from an international disease registry
}

Marc C Patterson ${ }^{1,8^{*}}$, Eugen Mengel ${ }^{2}$, Frits A Wijburg ${ }^{3}$, Audrey Muller $^{4}$, Barbara Schwierin ${ }^{4}$, Harir Drevon $^{5}$, Marie T Vanier ${ }^{6}$ and Mercé Pineda ${ }^{7}$

\section{Correction}

After the publication of this work [1] it was brought to the authors attention that Figure 1 contained an inversion in the color of the triangles, where yellow which should be "diagnosis" is said to be "first miglustat use", and blue which should be "first miglustat use" is said to be " diagnosis". The correct figure is given below:

\begin{abstract}
Author details
${ }^{1}$ Mayo Clinic, Rochester, MN, USA. ${ }^{2}$ Villa Metabolica, ZKMM, MC, University of Mainz, Mainz, Germany. ${ }^{3}$ Academic Medical Centre, University of Amsterdam, Amsterdam, The Netherlands. ${ }^{4}$ Actelion Pharmaceuticals Ltd, Allschwil, Switzerland. ${ }^{5}$ Numerus Ltd, Wokingham, UK. ${ }^{6}$ INSERM Unit 820, Lyon, France. ${ }^{7}$ Fundació Hospital Sant Joan de Déu, Barcelona, Spain. ${ }^{8}$ Department of Neurology, Mayo Clinic, 200 First Street SW, Rochester, MN 55905, USA.
\end{abstract}

Received: 7 May 2013 Accepted: 7 May 2013

Published: 14 May 2013

References:

1. Patterson MC, Eugen M, Wijburg FA, Audrey M, Barbara S, Harir D, Vanier MT, Mercé P: Disease and patient characteristics in NP-C patients: findings from an international disease registry. Orphanet Journal of Rare Diseases 2013, 8:12

\footnotetext{
* Correspondence: patterson.marc@mayo.edu

${ }^{1}$ Mayo Clinic, Rochester, MN, USA

${ }^{8}$ Department of Neurology, Mayo Clinic, 200 First Street SW, Rochester, MN 55905, USA

Full list of author information is available at the end of the article
}

\section{Submit your next manuscript to BioMed Central and take full advantage of:}

- Convenient online submission

- Thorough peer review

- No space constraints or color figure charges

- Immediate publication on acceptance

- Inclusion in PubMed, CAS, Scopus and Google Scholar

- Research which is freely available for redistribution

Submit your manuscript at www.biomedcentral.com/submit 


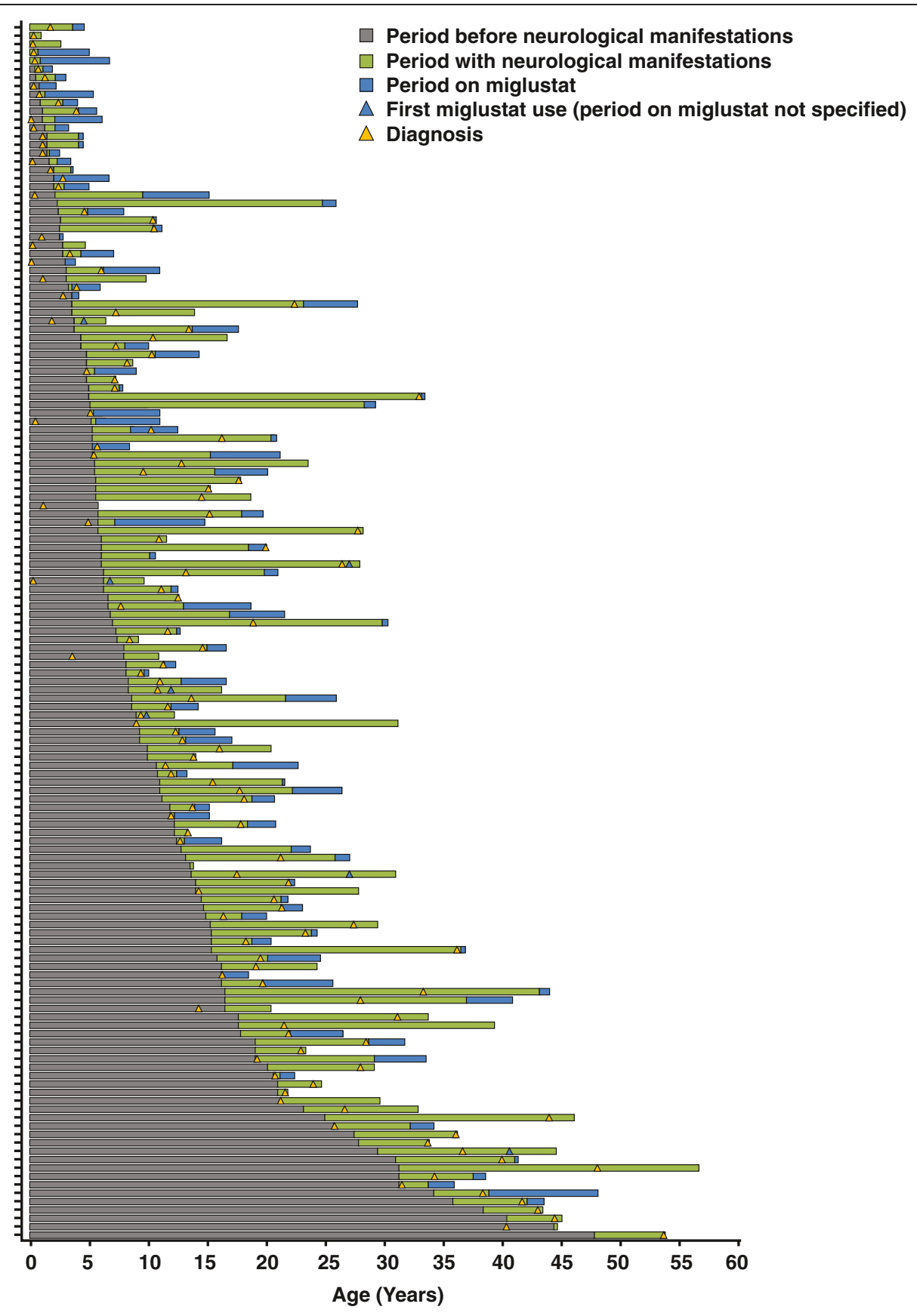

Figure 1 Overview of patient and disease characteristics. We regret any inconvenience that this inaccuracy may have caused. 